УДК 341.01

DOI https:/ / doi.org/10.32837 / yuv.v0i5.1996

T. Грабович,

кандидат юридичних наук

\title{
ЮРИДИЧНІ ПІДСТАВИ МІЖНАРОДНОЇ ВІДПОВІДАЛЬНОСТІ ДЕРЖАВИ
}

Постановка проблеми. Обгрунтоване притягнення держави до міжнародної відповідальності та унеможливлення неправомірного притягнення до відповідальності - один із проявів принципу юридичної рівності держав у міжнародному праві. Коли за однакових підстав одні держави притягаються до міжнародної відповідальності, а інші від неї можуть бути звільнені, або ж якщо для різних держав встановлюються неоднакові підстави відповідальності, то принцип юридичної рівноправності порушується, а міжнародна правосуб'єктність держав не поважається.

Питання про підстави міжнародно-правової відповідальності суб'єктів міжнародного права, що має велике теоретичне значення, найбільшої актуальності набуває на етапі притягнення держави до відповідальності в рамках міжнародного права. Зокрема, проблема виявлення підстав міжнародно-правової відповідальності виникає під час здійснення правозастосовчої діяльності міжнародними судовими органами, що розглядають спірні і неоднозначні ситуаціі та, по суті, повинні вирішити питання про наявність або відсутність у діях держави складу міжнародного правопорушення, визначити прийнятні форми міжнародно-правової відповідальності. Наявність достатніх підстав для міжнародно-правової відповідальності $€$ необхідною передумовою для виникнення правовідносин відповідальності і для заклику держави до виконання своїх зобов'язань, що випливають із вторинного правовідношення [1, с. 122].
Представники міжнародно-правової доктрини, які розглядають проблему підстав відповідальності держави, присвячують багато сотень сторінок переважно міжнародному правопорушенню. Однак уявляється, що через специфіку міжнародного права теоретично та практично важливим $є$ дослідження не тільки фактичних, а й юридичних підстав відповідальності держави [2, с. 60].

Стан дослідження. Питання міжнародної відповідальності держав розглядали у своїх працях такі науковці: С.С. Андрейченко, В.Ф. Антипенко, В.Г. Буткевич, Ю.Ю. Блажевич, К.А. Важна, В.Ю. Замятін, Ю.М. Колосов, Д. Кроуфорд, П.М. Куріс, Д.Б. Левін, I.I. Лукашук, В.А. Мазов, Г.I. Тункін, I.A. Ушаков, А. Фердросс та інші. Проте нині проблеми відповідальності держави в міжнародному праві далекі від свого вирішення. На відміну від внутрішньодержавного права, де питання підстав юридичної відповідальності висвітлюються досить широко, у міжнародно-правовій літературі проблемам підстав міжнародно-правової відповідальності держав не приділено належної уваги. Тому ці питання заслуговують на більш грунтовне вивчення.

Мета статті полягає у визначенні поняття та сутності юридичних підстав міжнародно-правової відповідальності держави, їх класифікації на основі аналізу сучасної доктрини та практики у сфері права міжнародної відповідальності.

Виклад основного матеріалу. Категорія «підстава юридичної відповідальності» містить дві взаємопов'язані 


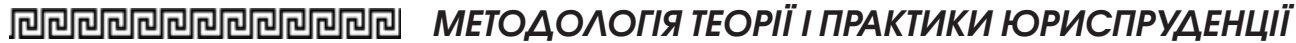

та водночас різні сторони, які відповідно виражаються в нормативних (правових) і юридико-фактичних підставах відповідальності, як зазначає П.M. Kуріс [3, с. 101]. На те, що термін «підстави юридичної відповідальності» уживається принаймні у двох значеннях, вказують I.C. Самощенко та M.X. Фарукшин: «По-перше, на підставі чого особа може нести юридичну відповідальність. У такому разі кажуть про закон, договір, норму права як підставу юридичної відповідальності; тобто йдеться про правову підставу юридичної відповідальності. Без заборони того чи іншого діяння законом, договором тощо юридична відповідальність $є$ неприпустимою. По-друге, за що особа може нести юридичну відповідальність. У цьому разі йдеться вже не про правову, а про фактичну підставу юридичної відповідальності, під якою розуміють дії людей і організацій, що заборонені правом» [4, с. 71-72].

Під нормативно-правовою підставою міжнародно-правової відповідальності низка авторів розуміють сукупність юридично обов'язкових міжнародно-правових актів, на основі яких певна поведінка або утримання від дій кваліфікуються як міжнародне правопорушення і через які суб'єкт міжнародного права повинен нести міжнародно-правову відповідальність [5, с. 464]. За висловлюванням В.А. Василенко, під юридичними підставами відповідальності держави за міжнародні правопорушення варто розуміти всю сукупність юридично обов'язкових приписів міжнародно-правових актів, на основі яких певний варіант поведінки держави кваліфікується як міжнародне правопорушення. У таких актах містяться явно виражені або побічні заборони, на підставі яких можна характеризувати той чи інший варіант дії держави як протиправний. Сукупність передбачуваних міжнародно-правовим актом ознак міжнародного правопорушення $€$ моделлю можливої протиправної поведінки держави, від конструкції якої буде багато в чому залежати характер регулятивно-охоронних правових відносин, що виникають у разі вчиненя суб'єктом діянь, заборонених приписом даного акта [2, с. 60].

Отже, під юридичними підставами міжнародно-правової відповідальності держави варто розуміти юридично дійсні міжнародні зобов'язання держави, незалежно від форми їх закріплення.

Міжнародний суд Організації Об'єднаних Націй (далі - OOH) у рішенні у справі “Rainbow Warrior” відзначив, що будь-яке порушення державою певного зобов'язання, незалежно від походження, призводить до відповідальності держави, отже, компенсування шкоди [6, с. 251]. У справі про дипломатичний та консульський персонал Міжнародний суд $\mathrm{OOH}$ зазначив, що для встановлення відповідальності Ірану треба розглянути, серед іншого, питання про те, наскільки відповіді діяння $€$ сумісними або несумісними iз зобов'язаннями Ірану за чинними договорами або за іншими нормами міжнародного права, що можуть бути застосовними [7, п. 56].

Формулювання «незалежно від форми походження» вказує на те, що міжнародні зобов'язання можуть встановлюватися звичаєвою нормою міжнародного права, договором або загальним принципом, що застосовується в рамках міжнародного правопорядку. Держави можуть брати на себе міжнародні зобов'язання за одностороннім актом. Міжнародне зобов'язання може випливати із процедур, передбачених у договорі (рішення органу міжнародної організації, яка має компетенцією у відповідній області, постанова Міжнародного суду або іншого трибуналу у справі, що стосується двох держав, та ін.). Зазначати такі варіанти немає необхідності, оскільки відповідальність держави виникає через порушення міжнародно-правового зобов'язання, незалежно від походження 
відповідного зобов'язання. Формула «незалежно від походження зобов'язання» позначає всі можливі джерела міжнародних зобов'язань, тобто всі процеси створення юридичних зобов'язань, визнані міжнародним правом. У цьому контексті іноді вживається слово «джерело», як, наприклад, у преамбулі Статуту ООН, де підкреслюється необхідність поваги до «зобов'язань, що випливають із договорів та інших джерел міжнародного права». Слово «походження» має таке ж значення, але водночас не дає приводу для сумнівів і наукових суперечок, що виникли у зв'язку з уживанням терміна «джерело» [8, с. 63].

Статті про відповідальність держав за міжнародно-протиправні діяння 2001 р. не містять як такого терміна «підстави відповідальності». Водночас зі змісту Статей та коментарів до них випливає, що йдеться про юридичні та фактичні підстави відповідальності. У пп. (b) ст. 2 Статей, що визначає умови, необхідні для встановлення наявності міжнародно-протиправного діяння держави, робиться посилання на порушення міжнародно-правового зобов'язання, а не будь-якого правила або норми міжнародного права. Значення для цих цілей має не просто наявність норми, а піi застосування до конкретного випадку відповідальної держави. Термін «зобов'язання» широко використовується в міжнародних судових рішеннях і практиці, а також в науковій літературі для охоплення всіх можливостей. Посилання на «зобов'язання» обмежується зобов'язанням за міжнародним правом [8, с. 39].

Конкретне діяння держави не може бути кваліфіковано як міжнародно-протиправне, якщо воно не порушує жодного міжнародно-правового зобов'язання такої держави. На таку кваліфікацію, згідно зі ст. 3 Статей про відповідальність держав 2001 р., не впливає кваліфікація цього діяння як правомірного за внутрішньодержавним правом.
Діяння держави не може бути кваліфіковано як міжнародно-протиправне, якщо воно не порушує міжнародно-правового зобов'язання, навіть якщо цією державою порушено припис власного законодавства. Навіть більше, держава не може посилатися на відповідність своєї поведінки приписам свого внутрішнього права, щоб ухилитися від кваліфікації своєї поведінки як протиправної згідно з нормами міжнародного права. Діяння держави має бути кваліфіковано як міжнародно-протиправне, якщо воно порушує міжнародно-правове зобов'язання, навіть тоді, коли дане діяння не суперечить внутрішньому праву держави, і навіть тоді, коли згідно із цим внутрішнім правом держава повинна була діяти саме таким чином [8, с. 39].

Так, зокрема, комітет ad hoc, створений для розгляду заяви про скасування арбітражного рішення, винесеного у справі «Хелнан інтернешнл Хотелз А/С» проти Арабської Республіки Єгипет ("Helnan International Hotels A / S v. Arab Republic of Egypt") (2010 р.), послався на ст. 3 Статей про відповідальність держав і стверджував, що «рішення місцевого суду <..> не може перешкоджати міжнародному арбітражу зробити інший висновок із застосуванням міжнародного права» [9, п. 51]. У справі "Рас Rim Casado Llc v. Republic of El Salvador" (2016 р.) арбітражний суд, із посиланням на ст. 3 Статей про відповідальність держав, зазначив, що «давно визнано, що в міжнародному арбітражі держава не може посилатися на норми свого внутрішнього законодавства у виправдання недотримання нею своїх міжнародних зобов'язань» [10, п. 5.62].

Погляди на класифікацію юридичних підстав міжнародної відповідальності держави не $€$ однозначними. Спеціальний доповідач із теми міжнародної відповідальності держави Р. Аго наголосив, що зобов'язання, порушення якого є складовим 


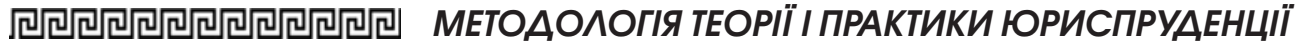

елементом міжнародного правопорушення, не повинне неодмінно випливати з норми, принаймні у вузькому значенні цього терміна. Зобов'язання може бути покладене на суб'єкта особливим правовим актом або рішенням суду чи арбітражної установи, рішенням міжнародного органу. Порушення зобов'язання, що має такий характер і походження, з позиції міжнародного права є настільки ж протиправним, як і невиконання зобов'язання, встановленого власне нормою [11, с. 192].

В.А. Василенко поділяє міжнародно-правові акти, що можуть бути джерелами юридичних підстав відповідальності держави за міжнародні правопорушення, на три групи: 1) міжнародний договір та міжнародний звичай; 2) рішення міжнародних судів і рішення міжнародних (міжурядових) організацій, що мають обов'язкову силу; 3) окремі односторонні міжнародно-правові акти держав. Науковець слушно зауважує, що будь-який правомірний міжнародно-правовий акт, що містить юридично обов'язкові правила поведінки, $€$ джерелом юридичних підстав відповідальності держави [2, с. 61].

Загалом джерела міжнародно-правової відповідальності збігаються із джерелами міжнародного права. Але це не $є$ правилом. Нормативно-правовою підставою відповідальності завжди є рішення міжнародних судів і арбітражів. Водночас у науці міжнародного права їх не визнають джерелами міжнародного права або визнають (обмежене коло фахівців) лише як допоміжні джерела. Правовою підставою міжнародно-правової відповідальності можуть бути спеціальні правові акти, які покладають відповідальність на суб'єктів міжнародного права, але не $€$ джерелом міжнародного права. Підставою для такої відповідальності можуть бути рішення міжнародних органів, односторонні акти, які також не $€$ джерелами міжнародного права (В.Г. Буткевич, О.В. Задорожній, В.В. Мицик) [5, с. 464].
Як зазначає А.Є. Русецький, за наявності міжнародного правопорушення порушується не міжнародно-правова норма як така, а зобов'язання суб'єктів дотримуватися міжнародного правила поведінки. Тому перелік джерел юридичних підстав відповідальності ширше, ніж коло джерел міжнародного права [12].

Отже, систему юридичних підстав міжнародно-правової відповідальності держав становлять: міжнародний договір; міжнародний звичай; юридично обов'язкові рішення міжнародних міжурядових організацій; рішення міжнародних судів та арбітражів; односторонні акти держав.

Варто наголосити, що юридичні підстави можуть розглядатися виключно в їхньому взаємозв'язку 3 фактичними підставами міжнародної відповідальності держави. Наявності лише однієї з них, безперечно, недостатньо для притягнення держави до міжнародно-правової відповідальності. Щоб правовідношення відповідальності виникло, необхідне не тільки нормативно-правове закріплення зобов'язання держави з гіпотетичною можливістю притягнення до відповідальності за порушення цього зобов'язання, а й фактичне невиконання цього зобов'язання. I навпаки, фактична дія або бездіяльність держави як така не має значення для цілей притягнення іï до відповідальності. Одного лише присвоєння державі будь-якого діяння недостатньо для виникнення правовідносин відповідальності [1, с. 123].

Висновки. Отже, під юридичними підставами міжнародно-правової відповідальності держави варто розуміти юридично дійсні міжнародні зобов'язання держави, незалежно від форми ï закріплення (міжнародний договір, міжнародний звичай, юридично обов'язкові рішення міжнародних міжурядових організацій, рішення міжнародних судів і арбітражів, односторонні акти держав). 


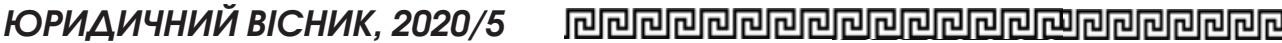

Питання юридичних підстав настання відповідальності держав $€$ одним із найважливіших у сфері права міжнародно-правової відповідальності. Існує тісний зв'язок між належним визначенням підстав міжнародної відповідальності, їх застосуванням на практиці та принципом рівноправності держав у міжнародних відносинах. Щоб пов'язати відповідальність із діяннями держави, поведінка повинна являти собою порушення певного міжнародно-правового зобов'язання, що $є$ чинним для держави на певний момент часу [8, с. 36]. Точне встановлення підстав міжнародно-правової відповідальності держави, як юридичних, так і фактичних, сприяє забезпеченню законності в міжнародному праві, надає необхідні гарантії прав для учасників міжнародних правовідносин.

Стаття спрямована на визначення поняття та сутності юридичних підстав міжнародно-правової відповідальності держави та ї класифікацію на основі аналізу сучасної доктрини та практики у сфері права міжнародної відповідальності. Встановлено, що обтрунтоване притягнення держави до міжнародної відповідальності та унеможливлення неправомірного притягнення до відповідальності є одним із проявів принциипу юридичної рівності держав у міжнародному праві. Обтрунтовано, що під юридичними підставами міжнародно-правової відповідальності держави варто розуміти юридично дійсні міжнародні зобов'язання держави, незалежно від форми їх закріплення. Формулювання «незалежно від форми походження» вказує на те, що міжнародні зобов'язання можуть встановлюватися звичаєвою нормою міжнародного права, договором або загальним принципом, що застосовується в рамках міжнародного правопорядку. Держави можуть брати на себе міжнародні зобов'язання за одностороннім актом. Міжнародне зобов'язання може випливати iз проиедур, передбачених у договорі (рішення органу міннародной організації, яка має компетенцією y відповідній області, постанова Міннародного суду або іншого трибуналу у справі, що стосуеться двох держав, та інше).

Встановлено, що конкретне діяння держави не може бути кваліріковано як міннародно-протиправне, якщо воно не порушуе жодного міжнародно-правового зобов' язання такої держави. На таку кваліфікацію, згідно зі статmею 3 Cmaтей про відповідальність держав 2001 року, не впливає кваліфікація цього діяння як правомірного за внутрішньодержавним правом. Зроблено висновок, щз систему юридичних підстав міжнародно-правової відповідальності держав становлять: міжнародний договір; міжнародний звичай; юридично обов'язкові рішення міжнародних міжурядових організацій; рішення міжнародних судів та арбітражів; односторонні акти держав. Юридичні підстави можуть розглядатися виключно в їхньому взаємозв'язку з фактичними підставами міжнародної відповідальності держави. Наявності лише однієї з них, безперечно, недостатньо для притягнення держави до міжнародно-правової відповідальності. Доведено, що точне встановлення підстав міжнародно-правової відповідальності держави, як юридичних, так $i$ фактичних, сприяе забезпеченню законності в міжнародному праві, надае необхідні гарантї прав для учасників міжнародних правовідносин.

Ключові слова: міжнародна відповідальність держави, юридичні підстави міжнародної відповідальності, джерела міжнародного права, Статті про відповідальність держав за міжнародно-протиправні діяння. 


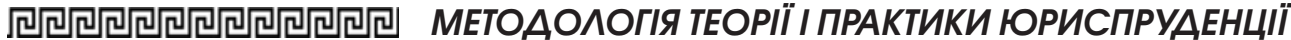

\section{Grabovich T. Legal grounds of state responsibility}

The article is aimed at defining the concept of the legal grounds of international responsibility of the state and their classification based on the analysis of modern doctrine and practice of the law of international responsibility. It is established that reasonable invocation of responsibility is one of the manifestations of the principle of legal equality of states in international law. It is substantiated that the legal grounds of the international responsibility of the state should be understood as legally valid international obligations of the state, regardless of the form of origin. The wording "regardless of the form of origin" indicates that international obligations may be established by a customary rule of international law, a treaty or a general principle applicable within the framework of international law, or by unilateral act. An international obligation may follow from the procedures provided for in the treaty (a decision of a body of an international organization with jurisdiction in the relevant field, a ruling of the International Court of Justice or another tribunal).

It is established that a conduct of a state cannot be qualified as internationally wrongful if it does not violate any international obligation of such a state. The characterization of a conduct as internationally wrongful is independent of its characterization as lawful under the internal law of the State. It is concluded that the system of legal grounds of international responsibility of states consists of: international agreement; international custom; legally binding decisions of international intergovernmental organizations; decisions international courts and arbitrations; unilateral acts of states. Legal grounds can be considered only in their relationship with the factual grounds of international responsibility. It is proved that the precise establishment of the grounds of international responsibility, both legal and factual, contributes to the rule of law in international law, providing the necessary guarantees of rights for participants in international legal relations.

Key words: international responsibility of state, legal grounds of international responsibility, sources of international law, Articles on responsibility of states for internationally wrongful acts.

\section{Література}

1. Курдюков Г.И., Кривенкова М.В. Основания международно-правовой ответственности государства: от теории к практике отдельных международных судебных органов. Журнал российского права. 2016. № 9. С. 121-129.

2. Василенко В.А. Ответственность государства за международные правонарушения. Киев: Виша школа, 1976. 267.

3. Курис П.М. Международные правонарушения и ответственность государства. Вильнюс : Минтис, 1973. 279 с.

4. Самощенко И.С., Фарукшин М.X. Ответственность по советскому законодательству. Москва: Юрид. лит-ра, 1971. 240 с.

5. Міжнародне право : основні галузі : підручник для студентів вищих навчальних закладів / В.Г. Буткевич та ін. ; за ред. В.Г. Буткевича. Київ : Либідь, 2004. 814 с.

6. Rainbow Warrior (New Zealand/ France). Reports of International Arbitral Awards. Vol. 20. New York, 1990.

7. United States Diplomatic and Consular Staff in Tehran (Hostages) case. 1980. ICJ Reports. 1980. P. 3.

8. Доклад Комиссии международного права о работе ее пятьдесят третьей сессии. Ежегодник комиссии международного права. 2001. T. II. Ч. 2. A/CN.4/SER.A/2001/Add.1 (Part 2). URL: https: / / legal.un.org / ilc/ reports / 2001 / russian/chp4.pdf.

9. ICSID. Case № ARB/05/19. Decision of the ad hoc committee. 14 June 2010.

10. ICSID. Case № ARB/09/12. Award 14 October 2016.

11. Second report on State responsibility by Roberto Ago. A/CN.4/233. Extract from the Yearbook of the International Law Commission. 1970. Vol. II.

12. Русеикий А.Е. Понятие и основания международно-правовой ответственноcmu. 2001. URL: http: / / wwr.law.edu.ru/ doc/document.asp?docID $=1137263$. 